\title{
GD2 Antibody
}

National Cancer Institute

\section{Source}

National Cancer Institute. GD2 Antibody. NCI Thesaurus. Code C129921.

Any immunog lobulin that recognizes gang lioside GD2. 